\title{
THE ECONOMIC RELEVANCE OF ON-SITE CONSTRUCTION ACTIVITIES WITH THE EXTERNAL THERMAL INSULATION COMPOSITE SYSTEM (ETICS)
}

\author{
Virgo SULAKATKO (D) ${ }^{1,2}$, Irene LILL (D) ${ }^{1, *}$ \\ ${ }^{1}$ Department of Civil Engineering and Architecture, Building Lifecycle Research Group, Tallinn University of \\ Technology, Tallinn, Estonia \\ ${ }^{2}$ Institute of Civil Engineering, Technical University of Berlin, 10623 Berlin, Germany
}

Received 23 September 2018; accepted 07 December 2018

\begin{abstract}
The systematic inadequacies of the External Thermal Insulation Composite System (ETICS), which occur during the construction phase, increase the financial risk for stakeholders, while reducing the long-term durability of the facade. The economic effect of on-site shortcomings can be reduced if the most significant on-site activities are recognised. The current paper develops an economic relevance assessment model for on-site construction activities of ETICS to increase economic rationality of resource allocation and emphasise the high-risk systematic shortcomings. The economic assessment model quantifies the financial risk of the on-site degradation factors with the method of modified Failure Mode Effects Analysis (FMEA). The data collection is followed by experts' judgments and is validated with the Delphi technique. The study reveals that degradation factors in the early phases of construction have the highest relevance due to high costs of repair as well as high occurrence possibility and higher detection difficulty due to rapid coverage. Ninety percent of the shortcomings appear during the first five years of completion of the construction. The on-site failures occurring during the application of mechanical anchors and finishing layer cause the lowest financial risk. The model enables the economic effect of the on-site activities to be prioritised for better resource allocation.
\end{abstract}

Keywords: ETICS, risk management, economic model, project management, quality, building technology.

\section{Introduction}

The European Commission has indicated that by 2020 all new builds must be Nearly Zero-Energy Buildings (NZEBs) to meet the European climate strategy targets. The energy use reduction will have to be achieved largely through the renovation of existing buildings. Using a thin-layer rendering system on the building's exterior facade is one refurbishment possibility. In European countries, the usage of the External Thermal Insulation Composite System (ETICS) and the interest in the aspects of construction quality are increasing. Until now the features of on-site construction process management and building technology on the quality of ETICS have been studied in isolation and comparison of different research findings have received too little attention. It is important to understand that shortcomings in the construction process and different construction technology aspects have an essential impact on future costs.

The technical aspects of ETICS degradation have interested researchers over many decades. H. Künzel, H. M. Künzel, and Sedlbauer (2006) and Gaspar and De
Brito (2008) have observed the long-term performance of the system. Neumann (2009), Kussauer and Ruprecht (2011) and Cziesielski and Vogdt (2007) have published specialized books on the causes of such degradations. Flores-Colen and De Brito (2010) have approached the aspect of economic rationality of ETICS with the focus on maintenance and are observing the visible signs of the defects. These and many other studies point out a large number of possible deviations, which can occur during the construction process and have a severe impact on the quality of the system.

This study focuses on the shortcomings during the onsite construction process of ETICS with an emphasis on their impact on future costs. Woodward (1997), Skitmore and Marston (1999) have stated that construction technology and quality are in correlation to cost. The elimination of shortcomings after completion takes more effort and resources in comparison to their avoidance during the primary installation process. Due to this snowballing economic effect, it is relevant to realise which activities

${ }^{*}$ Corresponding author. E-mail: irene.lill@ttu.ee 
have high impact and how to conduct the tradeoff between the future repair costs and quality assurance in the early construction phase.

Failure Mode Effects Analysis (FMEA) is a risk prioritisation method, which considers the severity, occurrence and detectability of shortcomings. Although it is widely used in production, some studies (Abdelgawad \& Fayek, 2010; Layzell \& Ledbetter, 1998; Mecca \& Masera, 1999) have implemented the method in the construction industry. Traditionally, the severity consideration focuses on the impact of technical severity. Bowles (2003) has argued that the financial aspect is undervalued to give recommendations on risk reduction. Similar research which uses financial aspects as severity input for FMEA has been conducted by Shafiee and Dinmohammadi (2014) for the production and erection of wind turbines. They point out that there is a relevant difference in future cash flows if offshore or onshore placement is observed. Their research is focused on the cost of the failure consequences, which supports managers in their investment decision-making process. The economic risk assessment concluded that the financial relevance is beneficial as more detailed considerations are required from the operational phase to evaluate the ultimate effects of the shortcomings.

There are two major points criticizing the usefulness and interpretation of FMEA models, which have been modified by including the financial aspects. The general criticism is focused on the calculation of the Risk Priority Number, which multiplies the variables without any weighting factor (Bowles, 2003; Carmignani, 2009; Pillay \& Wang, 2003). The researchers argue that the occurrence and detectability values should not be linear. The second aspect is focused on the difficulty of predicting the corrective action cost (Bowles, 2003; Carmignani, 2009). This model observes the specific façade system of ETICS, which reduces the number of repair methods and data requirements from a specific company. The data is gathered from actual construction projects, which represents the current economic situation and is reliable. It can be agreed that many variables change - the location of the project, the economic situation, and the cost of artisans and materials, and therefore, the cost data should be project-specific. The repair methods are also subject to change as alternatives emerge or are more relevant.

This paper develops an ETICS economic assessment model, which considers the future cost of shortcomings as the variable of severity with the modified FMEA method. The on-site shortcomings are evaluated according to their repair methods, detectability during the construction works and their occurrence probability. The results enable resources to be identified and allocated during the construction process on the activities, which have a higher financial impact.

\section{Materials and methods}

The economic evaluation focuses on the costs caused by degradation factors, which occur during the construction process of ETICS. The aim is to develop an economic comparison system to differentiate the construction pro- cess shortcomings by their financial relevance. The FMEA modified risk assessment methodology is applied to classify and rate the significance of each failure separately.

The FMEA approach has been proven to be a flexible model which can be adapted according to the specific needs of the user. Traditionally, the severity evaluation focuses on the technical impacts of a failure. In this model, the risk differentiation focuses on the economic impact and is therefore substituted for economic value. Shafiee and Dinmohammadi (2014) have shown the value of such differentiation for decision making on the shortcomings of on-shore and off-shore wind turbine assembly, where the repair costs vary to a large extent. Rhee and Ishii (2003) have pointed out the need to include costs into the risk calculation approach and developed a "Life Cost-Based FMEA" which includes traditional FMEA, Life Cycle Costs and Service Mode Analysis. Carmignani (2009) included in the developed FMECA model the cost of preventive action, which enables the estimated profitability be calculated if measures are taken. These FMEA modifications point out the relevance of cost in risk management as it is the expected benefit for reducing the systematic failure during the process.

The outcome of the economic relevance calculation for each degradation factor is the economic risk priority number $\left(\mathrm{ERPN}_{\mathrm{DF}}\right)$, calculated as follows:

$$
E R P N_{D F}=E A V_{D F} \times O V_{D F} \times D V_{D F},
$$

where: $E R P N_{D F}$ - economic risk priority number; $E A V_{D F}$ - economic assessment value of a degradation factor; $D V_{D F}$ - detectability of the degradation factor; $O V_{D F}$ - likelihood of occurrence.

ERPN is the value of a single degradation factor which enables the prioritization and comparison to other evaluated factors. Although the repair costs include the actual costs in monetary units provided by the user of the model, the ERPN expresses the criticality without a specific unit. The development procedure of the model defines the components required for the calculation of the economic impact as shown in Figure 1. The economic model is influ-

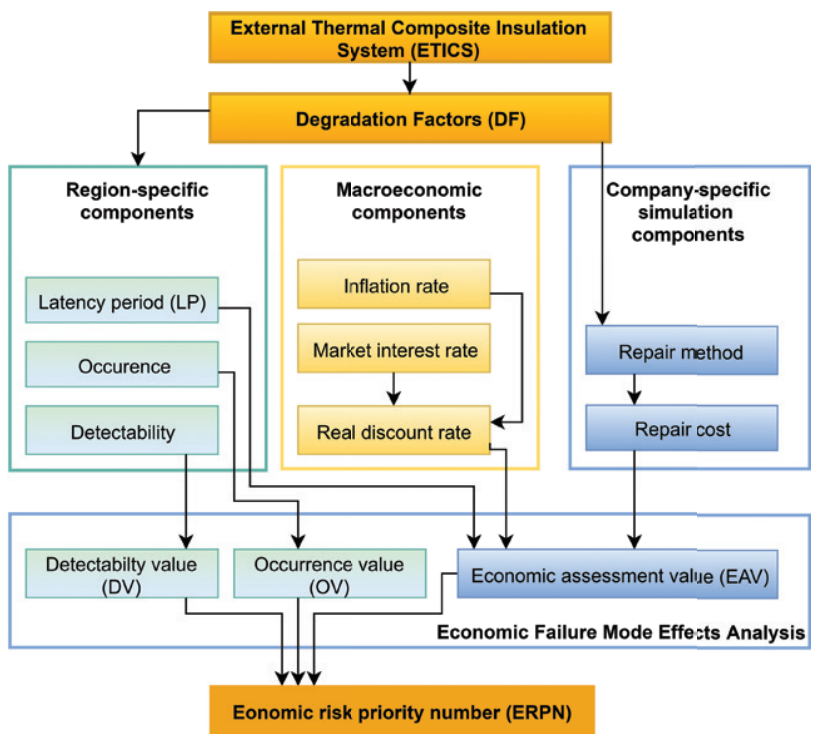

Figure 1. The concept of the economic risk assessment model 
enced by regional, macroeconomic and company-specific components, which are the input values to the calculation of ERPN. The following chapters describe the method for selection of degradation factors, data collection and calculation steps as well as the characteristics of the sample simulations.

\subsection{Degradation factors}

The list of degradation factors in the model involves different on-site contruction activities. The user of the model can introduce new activities if required. The model is simulated for the shortcomings, which are collected and described in (Sulakatko, Liisma, \& Soekov, 2017). The authors have verified the degradation factors through two experts, as suggested by Converse and Presser (1986), who had experience with ETICS for more than 12 years. The experts were identified through the membership of a nationally recognized committee for ETICS. One expert who verified the list was located in Germany, had a doctoral degree, while the second expert was in Estonia, and had master's degree in the field of construction. The reviews were conducted individually and independently. Eventually 11 irrelevant factors were removed from further analysis, and the wording of 16 factors was rephrased in order to improve intelligibility. The list of factors is presented in the Appendix.

\subsection{Components of the model: latency period, detectability and occurrence probability}

For each degradation factor, the developed model requires data regarding detectability and occurrence probability as well as the latency period for the discounting of repair costs. The latency period is a time range between the occurrence of the on-site shortcoming and the time when the degradation has evolved and requires repair activities. The occurrence probability measures show the frequency of shortcomings, and detectability measures show how difficult these shortcomings are to notice during the construction works. As this study aims to identify the situation in Estonia, the Estonian experts were asked to participate in the region-specific data collection. The data was collectied with the single Delphi technique, where the judgements of independent and anonymous experts are combined through mathematical aggregation (Skulmoski \& Hartman, 2007).
There is no quantified data available on the research subject. Hence, expert judgement was suitable for use in this study. Indeed, the selection of experts considerably affects the quality of the data (Chan, Yung, Lam, Tam, \& Cheung, 2001). Therefore, the criteria of experts' selection were their in-depth knowledge in technical aspects of ETICS as well as practical on-site experience. According to Olson (2010), variations in reviewers' backgrounds are allowed. Hallowell and Gambatese (2010) suggested that in the construction industry, selection of experts could be conducted through nationally recognized associations or by participation in similar studies. The expert should meet at least four of the following requirements: (1) have at least five years of professional experience in the construction industry; (2) have a tertiary education degree in the field of civil engineering or other related fields; (3) be professional registered in the field of construction; (4) be a member or chair of a nationally recognized committee for ETICS; (5) be a writer or editor of a book or book chapter on the topic; (6) be a faculty member at an accredited institution of higher learning; (7) have been invited to present at a conference on the topic; and (8) be a primary or secondary writer of at least three peer-reviewed journal articles. Five Estonian experts out of seven identified agreed to participate in the survey conducted in 2018. Their practical experience in the field of ETICS was between 10 and 20 years and they hold tertiary education. All five have practical experience, three work in an ETICS manufacturing and retail company, and one works at a construction firm and one as supervisor.

For the evaluation of detectability and occurrence probability, 5-point Likert scales were developed. Preston and Coleman (2000) pointed out that a detectability value below four points should be avoided. The detectability value rates how difficult it is to detect the shortcoming on the construction site. The characteristics of the detectability classification are shown in Table 1.

Likelihood of occurrence rates incident frequency during the construction process. It is an expert's subjective evaluation and it is dependent on his/her personal experience. The pre-test questionnaire revealed that it is impossible to quantify the occurrences in a specific range and quantification of subjective evaluation is required. The rating scale is shown in Table 2, where ranks with the highest

Table 1. Likert scale for the evaluation of detectability

\begin{tabular}{|l|l|c|}
\hline \multicolumn{1}{|c|}{ Risk level } & \multicolumn{1}{|c|}{ Characteristic } & Detectability value \\
\hline Very high & $\begin{array}{l}\text { A potential cause of failure cannot be detected visually. Additional tests need to be used. } \\
\text { High experience required }\end{array}$ & 5 \\
\hline High & In-between very high and moderate conditions & 4 \\
\hline Moderate & $\begin{array}{l}\text { A potential failure can be detected visually before completion of the layer, during the } \\
\text { application process or through markings on the material packages. Mediocre experience } \\
\text { required }\end{array}$ & 3 \\
\hline Low & In-between very low and moderate conditions & 2 \\
\hline Very low & Cause of failure can be detected after completion of the layer by less experienced observer & 1 \\
\hline
\end{tabular}


Table 2. Likert scale for the evaluation of occurrence probability

\begin{tabular}{|l|l|c|}
\hline \multicolumn{1}{|c|}{ Risk level } & \multicolumn{1}{c|}{ Characteristic } & $\begin{array}{c}\text { Occurrence } \\
\text { value }\end{array}$ \\
\hline Very high & Failure is almost certain & 5 \\
\hline High & Often repeated failures & 4 \\
\hline Moderate & Occasional failures & 3 \\
\hline Low & Relatively few failures & 2 \\
\hline Very low & Failure is unlikely & 1 \\
\hline
\end{tabular}

value are set for the frequently occurring failures, and the lowest value for unlikely failures.

The latency period was detected with the accuracy of one year. The degradation factors which occur only due to unpredictable situations (i.e. outbroke of fire, vandalism) are marked as a happening in the year 0 . Additionally, it was considered that the latency period could not exceed the service life of ETICS. According to studies by FloresColen and De Brito (2010) and Künzel et al. (2006), the service life can be more than 35 but can decrease to 16 years if no maintenance is conducted. The average service life expectancy is 30 years (Pelzeter, 2007; Wetzel \& Vogdt, 2007), which is also used as the latency period limitation in this study. For the latency period, the experts predicted the year when the shortcoming shows visible signs. After the data collection, the mean values of the experts were calculated.

The most preferred number of panelists has not been determined in the literature as it depends on the availability of experts, the research topic and resources (Ameyaw, Hu, Shan, Chan, \& Le, 2016). Wilson (2017) emphasises the duration of the experience on the topic, which was the primary criterion for the selection of experts to the panel. A small number of experts has often been used in other studies of the construction industry. Six experts were identified and selected for a risk assessment of road projects (Thomas, Kalidindi, \& Ganesh, 2006) and five experts evaluated construction business risks (Dikmen, Birgonul, Ozorhon, \& Sapci, 2010). Studies have included from 3 to144 experts in the studies of various industries (Skulmoski \& Hartman, 2007) and from 3 to 93 panelists in the construction industry (Ameyaw et al., 2016). Hallowell and Gambatese (2010) proposed a panel size between 8-12, whereas Rowe and Wright (2001) suggested including five or more experts in the panel and pointed out that there are "no clear distinctions in panel accuracy" when the panel size varies from 5 to 11 experts. As this model is aimed at SMEs, it is expected that the size will be small. Therefore, at least five experts should be included to collect the data.

The experts were asked individually and anonymously to provide their evaluations. According to the questionnaire, each expert needed to provide evaluations for occurrence, detectability and latency period. To obtain a high response rate, a meeting time with each expert was individually organized. During the face-to-face meeting, the questionnaire was completed by the expert. The responses from all experts were summarized and mean values were calculated. The collective mean results were sent to each expert and they were asked to revise their evaluation or agree/disagree with the collective result. During the next two weeks, three participants agreed with the collective results. Two experts reviewed the group results after a reminding phone call and stated their agreement with consensus. The similar one-round method is exercised in environmental planning (Kuo \& Yu, 1999) and other civil engineering researches (Hartman \& Baldwin, 1995).

\subsection{Cost component of the model: economic assessment value}

The life cycle costing method reflects the expenses in each phase of the building (Li, J. Zhu, \& Z. Zhu, 2012). To simplify the economic considerations the current model focuses on the costs of initial construction and the repair costs at the time when the degradation factors show visible degradation signs. The data needs to differentiate the financial relevance of shortcomings and consider the future monetary value at the time when the investement will be needed. The discounting technique enables the longterm economic effect to be introduced and compares the future investments required during upcoming years. As the model is developed for the internal use of a company, it is beneficial as the results of different simulations conducted during various years are comparable. The retrospective short-term economic changes are introduced to the model with the construction cost index. The relevance of the constrction cost index is relevant only if the cost data is collected during dissimilar years; otherwise there is no effect to the simulation. The ratio which differentiates the financial relevance of the shortcomings is expressed with the following equation:

$$
E A V_{D F}=\frac{N P V_{D F}}{C C I},
$$

where: $E A V_{D F}$ - economic assessment value [monetary unit $\left./ \mathrm{m}^{2}\right] ; N P V_{D F}$ - discounted repair costs of a degradation factor [monetary unit $/ \mathrm{m}^{2}$ ]; $C C I$ - construction cost index.

The discounted repair costs of a degradation factor are leveraged with the construction cost index for new residential buildings provided by Eurostat to maintain the comparability during economic fluctuations. The simulations in this research are based on the Estonian situation, where the value of quarter 4 in 2017, compared to 2010 as a reference year, is $116.6 \%$ (Eurostat, 2018).

A repair method is the set of construction activities required to remove the defect and restore the functionality of ETICS. Professionals in the field (Amaro, Saraiva, de Brito, \& Flores-Colen, 2014; Cziesielski \& Vogdt, 2007; Fraunhofer IRB Verlag, 2016; Krus \& Künzel, 2003; Kussauer \& Ruprecht, 2011; Neumann, 2009) thoroughly describe the reliable repair methods for ETICS. Maintenance techniques like cleaning, disinfecting and coating the external layer, or crack filling, required due to externally applied 
forces or ageing, are not observed. The defects caused by shortcomings in the sealants of additionally fixed details and roof edges are handled as a requirement to remove the insulation as moisture-induced problems have been caused. The possibility to cover degradated ETICS with second ETICS was not observed; instead the reapplication of the whole system was considered. As the current simulation model is explicitly developed for systematic on-site shortcomings of ETICS, the scope of works can be specified by the affected layers (Sulakatko, Lill, \& Liisma, 2015) - replacement of the finishing layer, reinforcement layer, or the whole system.

For the cost comparison, all the cost components of the model are adjusted to the unit $€ / \mathrm{m}^{2}$ without VAT. In this study the economic relevance model is simulated on three different project-based cost scenarios. The characteristics of the simulations are shown in Table 3.

The usage of industry data has provided valuable and more exact results in other studies (Serpell, 2004). Therefore the cost data for the simulations is provided by an experienced professional from one active construction company and is based on the costs of projects simultaneously under construction from September 2017 until January 2018 in Estonia. The cost difference to construction costs of simulations is shown in Table 4 . The table shows the cost difference ratio to the initial construction cost of simulation 1 .

The repair techniques dismantle the existing system up to the defected layer and replace these by re-applying the layers. The utilisation of insulation materials is responsible on average for $50 \%$ of the dismantling costs, artisans for $21 \%$ and lifting mechanisms, covers and other minor accessories for $29 \%$. The repair costs are timerelevant components in the life cycle consideration and are calculated as follows:

$$
N P V_{D F}=\frac{C_{R}}{\left(1+R_{r}\right)^{L P_{D F}}},
$$

where: $N P V_{D F}$ - net present value of the repair costs for a degradation factor [monetary unit $/ \mathrm{m}^{2}$ ]; $R_{r}$ - real discount rate per annum [\%]; $L P_{D F}$ - latency period of a degradation factorm [years]; $C_{R}$ - repair cost of selected repair method [monetary unit $/ \mathrm{m}^{2}$ ].

\subsection{Real interest rate}

The discounting technique compares costs that take place in different time periods and the discount rate represents the time value of money. Although it is recommended to use the real discount rate of $2 \%$ for the LCC calculation by other researchers (Langdon, 2007), the inflation rate and the market interest rate provide a more specific outcome. The real interest rate is calculated as follows:

$$
R_{r}=R_{m}-R_{i},
$$

where: $R_{r}$ - real discount rate; $R_{i}$ - inflation rate; $R_{m}-$ market interest rate.

The economic relevance model focuses on the features of the Estonian market, and for the inflation rate the value of the harmonised consumer price index (HCPI) is used. The average of the 12 months harmonised inflation rate of a calendar year is shown in Figure 2a (Eurostat, 2017). In the case of Estonia, the inflation rate of $3.73 \%$ is applied. In comparison, the average HCIP in the European Union is $1,96 \%$, The selected long-term market interest rate is based on the national average interest reported by the national statistics of the central bank of Estonia. The average 5- to 10 -year loan interest rate for entrepreneurs is $4.25 \%$ as shown in Figure 2b (Bank of Estonia, 2017). The real interest rate in the NPV calculation is $0.52 \%$.

\subsection{Limitations}

The construction products are improving rapidly, and new construction technology emerges. The degradation factors as well as the data collected concern ETICS with the following characteristics:

- the subject is an existing multi-apartment building;

- external walls are made out of masonry or prefabricated concrete panels;

Table 3. Characteristics of simulations

\begin{tabular}{|l|l|l|c|l|}
\hline \multicolumn{1}{|c|}{ Simulation No. } & \multicolumn{1}{c|}{ ETICS type } & \multicolumn{1}{c|}{ Insulation type } & Insulation thickness & \multicolumn{1}{c|}{ Fixing method } \\
\hline Simulation 1 & ETICS 1 & Polystyrene & $200 \mathrm{~mm}$ & Purely bonded kit \\
\hline Simulation 2 & ETICS 2 & Polystyrene & $200 \mathrm{~mm}$ & $\begin{array}{l}\text { Mechanically fixed kit with } \\
\text { supplementary adhesive }\end{array}$ \\
\hline Simulation 3 & ETICS 3 & Mineral wool & $200 \mathrm{~mm}$ & $\begin{array}{l}\text { Mechanically fixed kit with } \\
\text { supplementary adhesive }\end{array}$ \\
\hline
\end{tabular}

Table 4. The comparative ratio of the construction and repair costs to the initial construction cost of simulation 1

\begin{tabular}{|l|c|c|c|}
\hline \multicolumn{1}{|c|}{ Description of construction work } & Simulation 1 & Simulation 2 & Simulation 3 \\
\hline The initial construction ETICS & 1.00 & 1.08 & 1.30 \\
\hline Replacement of insulation & 1.74 & 1.80 & 1.01 \\
\hline Replacement of reinforcement layer & 1.11 & 1.11 & 0.50 \\
\hline Replacement of finishing layer & 0.50 & 0.50 & \\
\hline
\end{tabular}




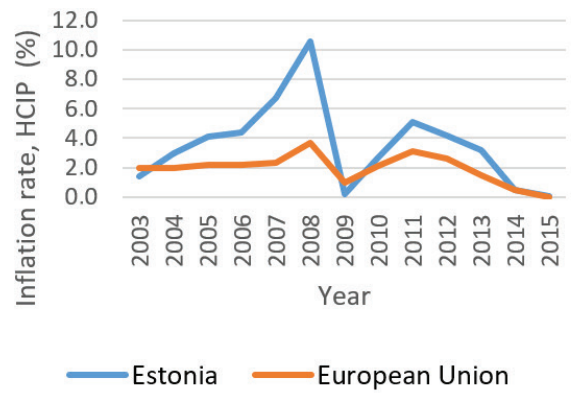

a)

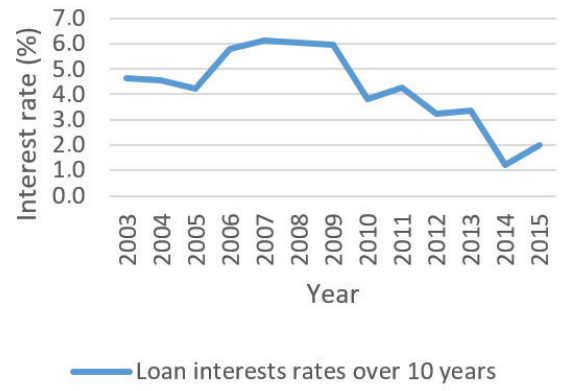

b)

Figure 2. a) Annual HCIP in Estonia and EU (Eurostat, 2017);

b) Interest rates in Estonia (Bank of Estonia, 2017)

- the fixing method is either purely bonded with adhesive or mechanically fixed with anchors and supplementary adhesive;

- reinforcement consists of the mixture and fiberglass mesh;

- the thermal insulation product is made out of mineral wool or expanded polystyrene with a thickness from $150 \mathrm{~mm}$ to $250 \mathrm{~mm}$;

- the simulations concern the economic situation of Estonia.

\section{Results}

\subsection{Latency period of the degradation factors}

The average latency period of the 103 degradation factors is 2.32 years with a standard deviation of 1.5 years; distribution by layers is shown in Figure 3. The correlation and linear regression analysis between the latency period, occurrence and detectability did not reveal relevant results.

The degradation factors in the layers of reinforcement, finishing coat and additional details do not depend on the system (simulation) and have an equal latency period. The layers of substrate, adhesive and insulation have a noticeable difference in comparison to the ETICS types under observation. The degradation factors that concern ETICS 3 have the longest latency period. In the layer on insulation, the difference is caused by two shortcomings - insulation material open to UV radiation for a longer period (I1)

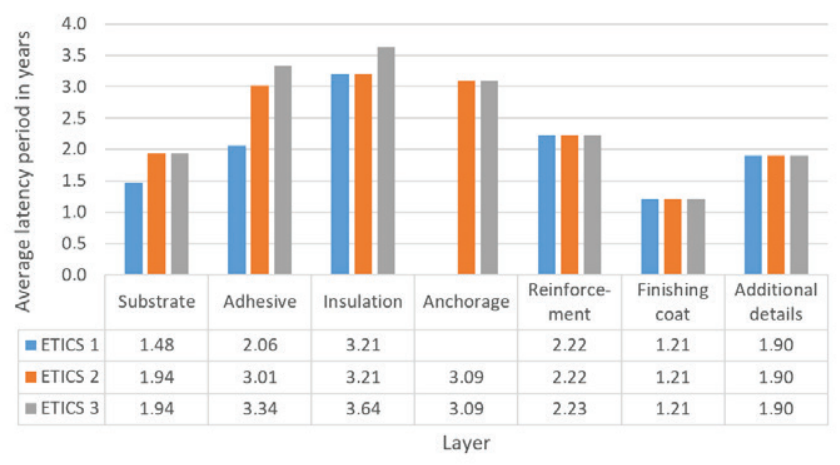

Figure 3. The average latency period by layer and continuing diffusion process of the insulation material (I2). Both are relevant for the polystyrene-based insulation and decrease the average value of the systems. The difference in the layer of adhesive is due to the fixing mechanism. ETICS 1 depends highly on the properties of adherence. ETICS 2 and ETICS 3 are primarily mechanically fixed, and the relevance of adhesive is significantly lower, as is the latency period. The layer of substrate is the most homogenous layer and shows the lowest standard deviation of 0.50 years.

Figure 4 reveals the latency periods of the degradation factors by the sequence of the construction process and draws the average values for different ETICS types by layer. The degradation factors in the layer of substrate appear rather fast. The latency period rises in the layers of adhesive and insulation and begins to fall after the installation of mechanical anchors. The shortcomings in the layer of reinforcement and finishing layer appear within the shortest period. The trend is similar for all the three ETICS types.

The groups LP1 and LP2 shown in Figure 4 have the longest latency period, above five years, and are relevant for their long-term durability. The layer of adhesive has a group of five degradation factors (LP1), which according to the discussion in the expert panel depend on the ap-

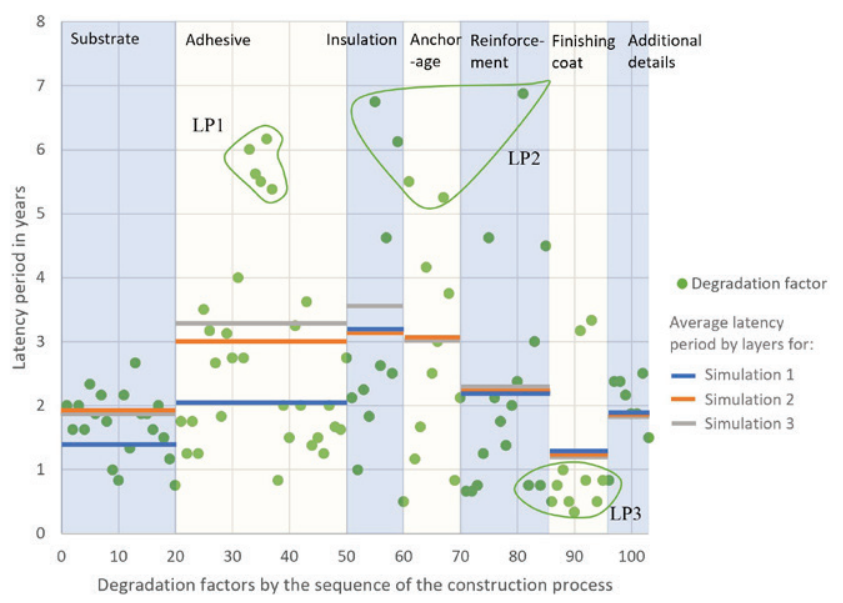

Figure 4. Latency period of the degradation factors by the sequence of the construction process 
pearance of natural disasters as well as ageing. The shortcomings in the group LP1 are insufficient adhesive (D3a, $\mathrm{D} 3 \mathrm{~b}$ ), adhesive not rubbed into mineral wool (D4a) or treated with a notch towel (D5) and exceeded working time of the mixture (D7a). The group LP2 concerns five factors from several layers - decreased diameter of anchor plate (A2), increased diameter of anchor hole (A1), crossed joints of insulation plates (I5), broken and not properly filled insulation plates (I9) and usage of not compatible mesh (R8), The glass fibre mesh in the base coat is required to be resistant to the alkaline environment. In the case of non-resistant mesh application, the required residual strength properties will be reduced until a critical level is achieved and failure of the system occurs.

The group LP3 diverges with a very low latency period. The majority in this group belongs to the finishing layer, and eight degradation factors out of ten in the finishing layer reveal problems during the first year after application. The two factors with high values are the thin render layer (F4) and high kneading water share (M3d) with a latency period of 3.2 and 3.3 years accordingly. However, both degradation factors have low occurrence and detectability values as shown in the next sub-chapter. Low values state that the shortcomings happen rarely and have good visibility.

The net present value calculations take into account the latency period, which is relatively low, as is its impact on the results. The maximum change of economic assessment value through NPV calculation was 3.5\%. To compare the difference of the results between the simulations, each shortcoming is appointed to a suitable simulation. The average values of economic assessment values for applicable shortcomings are shown in Figure 5. In the comparison between layers, lower repair costs have the degradation factors in the layers of anchorage and reinforcement, while the finishing layer has the lowest values in general.

\subsection{Probability of occurrence and detectability during construction works}

The discussed economic value is the first component in the ERPN calculation, while the occurrence and detectability values are the second and third components. To give an overview of the influence of the components, Figure 6 presents the average impact of the two factors by layer and Figure 7 visualizes the impact of the degradation factors according to their sequence in the construction process. Higher values show higher risks to consider. As

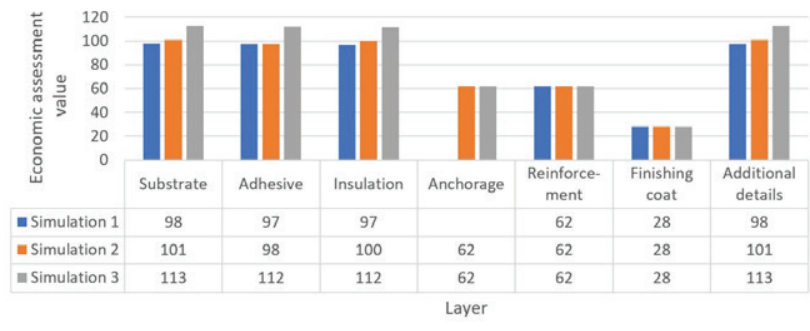

Figure 5. The average economic assessment value by layers

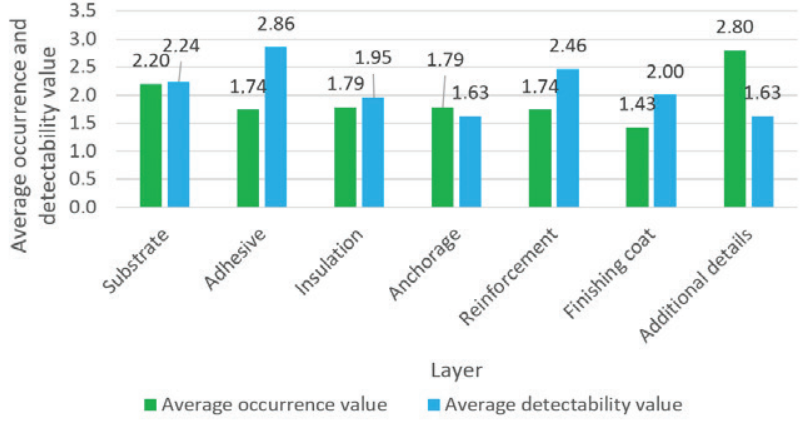

Figure 6. The average occurrence and detectability value by layers

no significant difference between ETICS types was found, the difference of average values is occurring only as some degradation factors are applicable for a specific system.

The figures show that higher occurrence values appear in the layers of substrate and additional details, while fewer shortcomings occur during the application of the finishing coat. The detectability value is the highest in the layers of adhesive and reinforcement as they can be observed only during the mixture application process. The standard deviation of the average values of the layers is between 0.31 and 0.76 . The lowest standard deviation for detectability of the shortcomings is in the layers of adhesive $(0.31)$, and additional details (0.33) visualised as groups DV1 and DV2 in Figure 7. These results are as expected as the detectability is more difficult by layer of adhesive due to fast coverage with insulation material, and the defects with additional details have relatively good visual detectability. For the occurrence value, lower standard deviation is found for the group OV1, shortcomings with anchorage (0.46). In other layers the standard deviation is above 0.5 and the distribution is higher.

\subsection{Economic risk priority number}

The average ERPN values by layer and simulation are shown in Figure 8. The highest priorities have the degradation factors in the layers of substrate, adhesive and additional details. The factors in the layer of insulation and reinforcement have modest values, while the mechanical anchors and the finishing coat are the least relevant.

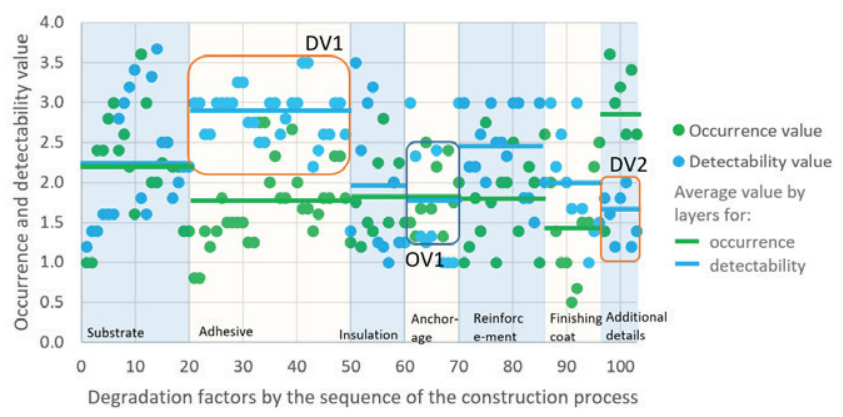

Figure 7. The average occurrence and detectability value of the degradation factors by the sequence of the construction process 


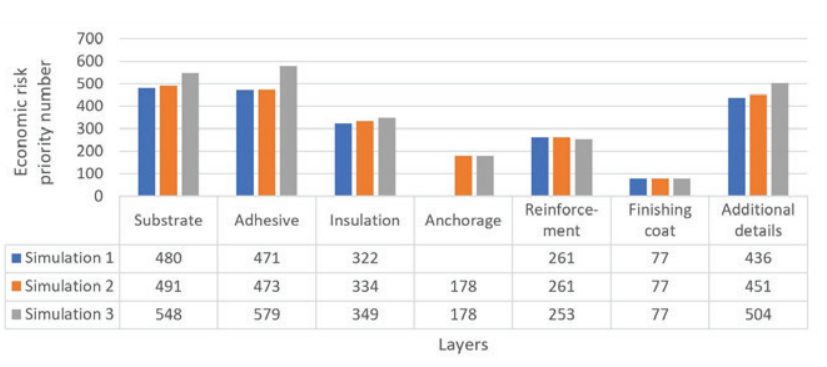

Figure 8. The average ERPN values by layer

In the layers of adhesive, substrate and additional details, simulation 3 shows increased relevance in comparison to the other simulations. According to the economic assessment values (Figure 5), the cause lies in the increased repair costs. A similar effect is in the layer of insulation on a smaller scale.

Figure 9 illustrates the ERPN values of the degradation factors in the sequence of the construction works and points out the approximate range of layers (colored areas). The horizontal lines show average ERPN for the three simulations by layer. There are groups of shortcomings with noticeable deviations, which are grouped by green lines. As the economic assessment value had a very low differentiation within a single layer, the major deviations occur due to the impact of the occurrence and detectability variables.

Group E1 in the layer of substrate describes the degradation factors in all three simulations and concerns the shortcomings which influence the adhesion properties as well as mechanical fixations. The adhesion properties are concerned by the remains of old paint (S4a, S4b), the low humidity of the existing wall (S7a, S7b) and unsuitable adhesive type (S7a, S7b). Also problematic is the loadbearing capacity of the external wall (S5a, S5b) as well as detached areas on the surface (S6a, S6b). Group E2 demonstrates very low risk and represents the external surface covered with oil (S1a, S1b), having very low occurrence and detectability values.

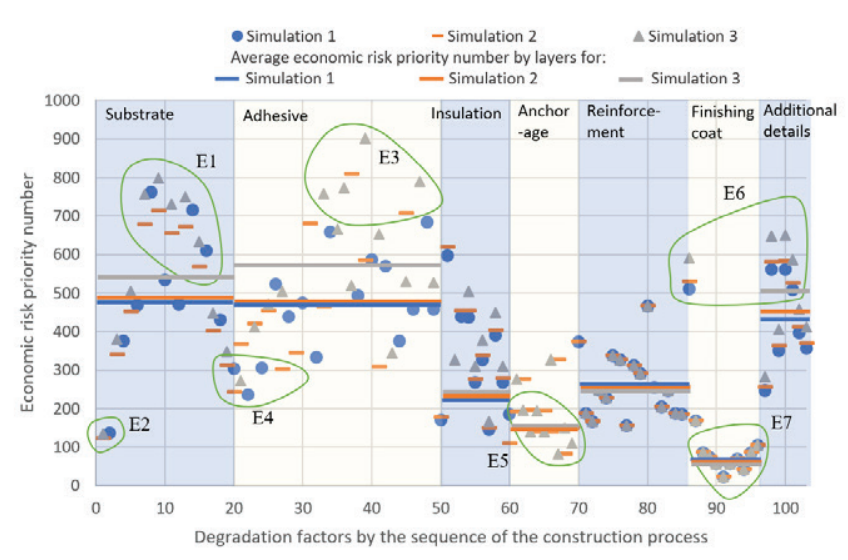

Figure 9. Economic risk priority number of the degradation factors by the sequence of the construction process
Group E3 involves the factors with high ERPN values in the layer of adhesive, which are relevant for simulation 2 and 3. Problems in simulation 2 occur as insufficient amount of adhesive applied (D3a), which is relevant for prohibiting air movement internally and has increased importance on the stability of the system. Additionally, the effect of exceeded working time (D7a) has high relevance. These degradation factors have relatively high detectability value as the shortcoming is covered with insulation plates immediately and are observable only during the application process. Simulation 3 is affected by lack of pressure on the installation plates during application (D8a) and no usage of notch towel (D5), leaving the possibility for air movement behind the system. Also, the drying out of the inorganic mixture due to high temperature (M11a) and dry curing conditions (M10a) are relevant.

Group E4 is a low relevance group which contains the freezing of adhesive due to a frozen external wall (S10a, $\mathrm{S} 10 \mathrm{~b})$. As the degradation factors refer to existing buildings which are heated by the habitants, it is expected that after the application of insulation, the temperature will not fall into a critical freezing zone. The other factors concern unsuitable adhesive storage conditions (M1a, M1b), clots in the mixture due to an insufficient mixing process (M2b) and a low share of kneading water (M4a). Although these factors have high economic assessment value, the occurrence and detectability reduce the relevance of risk noticeably. The other low relevance group, E5, representing 8 shortcomings out of 10 in the layer of mechanical anchors, has low values in all categories.

The high ERPN values concern group E6, which represents four degradation factors of additional details in all simulations. Due to the high repair costs and occurrence value, the factors of insufficient shock resistance measures (X6), unfinished windowsills (X2) and fixed frame connections (X4) as well as problematic roof edge covers (X5) have relatively high economic priority.

\section{Discussion}

The developed economic relevance model makes use of decision making when the future costs of possible shortcomings and the construction quality is targeted. The developed model enables the economic aspects to be included in the construction process risk assessment of ETICS. If during resource allocation on quality control of ETICS only direct costs are considered, the focus would be set on the internal layers as they require replacement of the whole system and cause higher repair costs (see Figure 5). By adding an occurrence probability and detectability component, the focus can be set only for the limited factors with higher risk. The added components reduced the relevance of the degradation factors in the layers of insulation and mechanical anchors. When the components are observed in silos, then the probability of occurrence increased the risk in the layer of the substrate and in additionally added details, while the detectability of the failures increased the risk in the layer of adhesive and reinforcement. 
In this model, the latency period has a relatively low effect on the results as it varies in a relatively small range most of the shortcomings appear during the first three years. A similar observation is made by Neumann (2009), who stated that $80 \%$ of the shortcoming occur during the first five years and $2 / 3$ occur in the first two years. According to the results of this study, 50\% occur during the first 2 -year period. Due to the short period, the interest rate has a relatively low impact on the results of this economic situation. However, the results of the latency period of the degradation factors can be interesting to various stakeholders of the project depending on their contractual agreement. If the contractual defect liability period is two years, then the financial risk is shifted from the contractor to the owner. Such degradation factors appeared more often in the layers of adhesive, insulation, anchorage and reinforcement as they have a longer latency period. These considerations enable decisions to be made on quality issues and the responsibilities of the parties on the contractual level.

Other studies consider the technical aspects in isolation and no comparative economic data is availible on the degradation signs. Several studies have investigated the durability aspects (Daniotti et al., 2012; Edis \& Türkeri, 2012; Künzel et al., 2006) and the deteroriaration signs and linked them with most probable direct and indirect causes (Amaro et al., 2014). The construction process defects cannot often be directly related to the visible anomalies as they require destructive tests. The results of the occurrence value contribute to studies conducted with such a top-down approach which investigate the in-situ analysis and require destuctive tests to understand the origin of the problem. These studies often imply several shortcomings that might have been the causes and are related to the technical aspects.

The previous study on the technical influence of the degradation factors (Sulakatko \& Vogdt, 2018) has emphasised the shortcomings in the layers of reinfocement and additional details as well as the works that influence the adhesion properties in the layers of substrate and adhesive of the purely bonded system. The average ERPN values in the layer of reinforcement are relatively low in this study. This shows that the resource allocation for quality insurance during the construction works must consider several variables.

\section{Conclusions}

The External Thermal Insulation Composite System (ETICS) can be used to modernize and increase the energy efficiency of existing and new buildings. However, the intensive on-site construction process aggravates the occurrence of systematic inadequacies. These inadequacies turn up as degradation signs and require additional resources for their elimination after the completion of the project. The financial relevance of construction activity is evaluated with the modified FMEA method, which considers the cost of repair as a severity variable of the onsite degradation factors. The model is simulated on three construction projects.
The results of the analysis show higher relevance of the on-site construction process activities in the layers of substrate and adhesive as they often occur, are hard to detect and have a high financial impact if repair activity is required. High relevance can also be noticed for the often-occurring problems during construction works with windowsills and roof edge covers. The results of the study finds that the shortcomings in the finishing layer and by mechanical anchors have the lowest relevance and that $90 \%$ of the degradation factors appear during the five-year period after construction, while half of them are visible as early as the first two years.

The economic assessment model enables the enhancement of financial risk assessment of the on-site construction process of ETICS to highly relevant construction activities. The outcome supports decision makers in increasing the value of the construction works by reducing future repair costs.

\section{Acknowledgements}

We would like to show our gratitude to the experts and participating construction company who have shared their experience and knowledge during this research.

\section{Funding}

This work was supported by the Estonian Ministry of Education and Research under Grant IUT-15 "Nearly-zero energy solutions and their implementation on deep renovation of buildings".

\section{Author contributions}

Virgo Sulakatko is the main author, he performed the research, collected data, conducted interviews and completed the analysis. Irene Lill supervised the activities in terms of methodology, framework and overall design of the research. Both authors contributed to discussion of results and recommendations, conclusions and the writing of the paper.

\section{Disclosure statement}

The authors declare no conflict of interests.

\section{References}

Abdelgawad, M., \& Fayek, A. (2010, September). Risk management in the construction industry using combined Fuzzy FMEA and Fuzzy AHP. Engineering and Management, 136, 1028-1037. Retrieved from http://ascelibrary.org/doi/ abs/10.1061/(ASCE)CO.1943-7862.0000210

Amaro, B., Saraiva, D., de Brito, J., \& Flores-Colen, I. (2014). Statistical survey of the pathology, diagnosis and rehabilitation of ETICS in walls. Journal of Civil Engineering and Management, 20, 1-16.

https://doi.org/10.3846/13923730.2013.801923 
Ameyaw, E. E., Hu, Y., Shan, M., Chan, A. P. C., \& Le, Y. (2016). Application of Delphi method in construction engineering and management research: a quantitative perspective. Journal of Civil Engineering and Management, 22(8), 991-1000. https://doi.org/10.3846/13923730.2014.945953

Bank of Estonia. (2017). Interest rates. Retrieved from http:// statistika.eestipank.ee/?lng=et\#listMenu/1071/treeMenu/FINANTSSEKTOR/147/979

Bowles, J. B. (2003). An assessment of RPN prioritization in a failure modes effects and criticality analysis. In Annual Reliability and Maintainability Symposium, 2003. (Vol. Annual, pp. 380-386). Tampa, Florida, USA.

https://doi.org/10.1109/RAMS.2003.1182019

Carmignani, G. (2009). An integrated structural framework to cost-based FMECA: the priority-cost FMECA. Reliability Engineering and System Safety, 94(4), 861-871. https://doi.org/10.1016/j.ress.2008.09.009

Chan, A. P. C., Yung, E. H. K., Lam, P. T. I., Tam, C. M., \& Cheung, S. O. (2001). Application of Delphi method in selection of procurement systems for construction projects. Construction Management and Economics, 19(7), 699-718. https://doi.org/10.1080/01446190110066128

Converse, J. M., \& Presser, S. (1986). Survey questions: handcrafting the standardized questionnaire. Beverly Hills: Sage Publications, Inc. https://doi.org/10.4135/9781412986045

Cziesielski, E., \& Vogdt, F. U. (2007). Schäden an WärmedämmVerbundsystemen (2nd ed.). Stuttgart: Fraunhofer IRB Verlag.

Daniotti, B., Cecconi, F. R., Paolini, R., Galliano, R., Ferrer, J., \& Battaglia, L. (2012). Durability evaluation of ETICS: analysis of failures case studies and heat and moisture transfer simulations to assess the frequency of critical events. In 4 th Portuguese Conference on Mortars and ETICS, 29-30 March. Coimbra, Portugal.

Dikmen, I., Birgonul, M. T., Ozorhon, B., \& Sapci, N. E. (2010). Using analytic network process to assess business failure risks of construction firms. Engineering, Construction and Architectural Management, 17(4), 369-386. https://doi.org/10.1108/09699981011056574

Edis, E., \& Türkeri, N. (2012). Durability of external thermal insulation composite systems in Istanbul Turkey. A Z Itu, 9(1), 134-148.

Eurostat. (2017). HICP all-items, development of the annual average inflation rates, 2005-2015. Retrieved from http://appsso. eurostat.ec.europa.eu/nui/submitViewTableAction.do

Eurostat. (2018). Construction Cost Index (CCI). Retrieved from http://ec.europa.eu/eurostat/tgm/refreshTableAction.do?tab= table\&plugin $=1$ \&pcode $=$ teiis510\&language $=$ en

Flores-Colen, I., \& De Brito, J. (2010). A systematic approach for maintenance budgeting of buildings facades based on predictive and preventive strategies. Construction and Building Materials, 24(9), 1718-1729.

https://doi.org/10.1016/j.conbuildmat.2010.02.017

Fraunhofer IRB Verlag. (2016). WTA Merkblatt 2-13. Wärmedämm-Verbundsysteme (WDVS) Wartung, Instandsetzung, Verbesserung. München, Germany.

Gaspar, P. L., \& De Brito, J. (2008). Quantifying environmental effects on cement-rendered facades: a comparison between different degradation indicators. Building and Environment, 43, 1818-1828. https://doi.org/10.1016/j.buildenv.2007.10.022

Hallowell, M. R., \& Gambatese, J. A. (2010). Qualitative research: application of the Delphi method to CEM research. Journal of Construction Engineering and Management, 136(1), 99-107. https://doi.org/10.1061/(ASCE)CO.1943-7862.0000137
Hartman, F. T., \& Baldwin, A. (1995). Using technology to improve Delphi method. Journal of Computing in Civil Engineering, 9(4), 244-249.

https://doi.org/10.1061/(ASCE)0887-3801(1995)9:4(244)

Krus, M., \& Künzel, H. M. (2003). Untersuchungen zum feuchteverhalten von fassaden nach hydrophobierungsmaßnahmen. WTA-Journal, 2(03), 149-166. Retrieved from http:// www.bauportal-zukunft.ru/forschungsberichte/PDF/12_Untersuchung_zum_Feuchteverhalten.pdf

Künzel, H., Künzel, H. M., \& Sedlbauer, K. (2006). Long-term performance of external thermal insulation systems (ETICS). ACTA Architectura, 5(1), 11-24. Retrieved from http://www. viking-house.ie/downloads/Long Term effect of Ext Insulation.pdf

Kuo, N. W., \& Yu, Y. H. (1999). An evaluation system for National Park selection in Taiwan. Journal of Environmental Planning and Management, 42(5), 735-745.

https://doi.org/10.1080/09640569910975

Kussauer, R., \& Ruprecht, M. (2011). Die häufigsten Mängel bei beschichtungen und WDVS (2nd ed.). Cologne, Germany: Rudolf Müller $\mathrm{GmbH} \&$ Co. KG.

Langdon, D. (2007, May). Life Cycle Costing (LCC) as a contribution to sustainable construction: a common methodology. In Final report summary. Davis Langdon management consulting.

Layzell, J., \& Ledbetter, S. (1998). FMEA applied to cladding systems - reducing the risk of failure. Building Research and Information, 26(6), 351-357. https://doi.org/10.1080/096132198369689

Li, W., Zhu, J., \& Zhu, Z. (2012). The energy-saving benefit evaluation methods of the grid construction project based on life cycle cost theory. Energy Procedia, 17, 227-232.

https://doi.org/10.1016/j.egypro.2012.02.088

Mecca, S., \& Masera, M. (1999). Technical risk analysis in construction by means of FMEA methodology. In W. Hughes (Ed.), 15th Annual ARCOM Conference (Vol. 2, pp. 425-434). Liverpool. Retrieved from http://www.arcom.ac.uk/-docs/ proceedings/ar1999-425-434_Mecca_and_Masera.pdf

Neumann, H. H. (2009). Praxis-handbuch wärmedämm-verbundsysteme. Baustoffkunde, verarbeitung, schäden, sanierung. Köln: Rudolf Müller.

Olson, K. (2010). An examination of questionnaire evaluation by expert reviewers. Field Methods, 22(4), 295-318. https://doi.org/10.1177/1525822X10379795

Pelzeter, A. (2007). Building optimisation with life cycle costs the influence of calculation methods. Journal of Facilities Management, 5(2), 115-128. https://doi.org/10.1108/14725960710751861

Pillay, A., \& Wang, J. (2003). Modified failure mode and effects analysis using approximate reasoning. Reliability Engineering \& System Safety, 79(1), 69-85. https://doi.org/10.1016/S0951-8320(02)00179-5

Preston, C., \& Coleman, A. (2000). Optimal number of response categories in rating scale: reliability, validity, discriminating power, and responding preferences. Acta Psychologica, 104, 1-15. https://doi.org/10.1016/S0001-6918(99)00050-5

Rhee, S. J., \& Ishii, K. (2003). Using cost based FMEA to enhance reliability and serviceability. Advanced Engineering Informatics, 17(3-4), 179-188. https://doi.org/10.1016/j.aei.2004.07.002

Rowe, G., \& Wright, G. (2001). Expert opinions in forecasting: the role of the Delphi technique. Principles of Forecasting. International Series in Operations Research \& Management Science, 30, 125-144. https://doi.org/10.1007/978-0-306-47630-3_7 
Serpell, A. F. (2004). Towards a knowledge-based assessment of conceptual cost estimates. Building Research \& Information, 32(2), 157-164. https://doi.org/10.1080/0961321032000172373

Shafiee, M., \& Dinmohammadi, F. (2014). An FMEA-based risk assessment approach for wind turbine systems: a comparative study of onshore and offshore. Energies, 7(2), 619-642. https://doi.org/10.3390/en7020619

Skitmore, R. M., \& Marston, V. (1999). Cost modelling. London: Taylor \& Francis. https://doi.org/10.4324/9780203979679

Skulmoski, G. J., \& Hartman, F. T. (2007). The Delphi method for graduate research. Journal of Information Technology Education, 6(1), 1-21. https://doi.org/10.28945/199

Sulakatko, V., Liisma, E., \& Soekov, E. (2017). Increasing construction quality of external thermal insulation composite system (ETICS) by revealing on-site degradation factors. Procedia Environmental Sciences, 38, 765-772.

https://doi.org/10.1016/j.proenv.2017.03.160

Sulakatko, V., Lill, I., \& Liisma, E. (2015). Analysis of on-site construction processes for effective external thermal insulation composite system (ETICS) installation. Procedia Economics and Finance, 21, 297-305. https://doi.org/10.1016/S2212-5671(15)00180-X
Sulakatko, V., \& Vogdt, F. U. (2018). Construction process technical impact factors on degradation of the external thermal insulation composite system. Sustainability, 10(11), 3900. https://doi.org/10.3390/su10113900

Thomas, A. V., Kalidindi, S. N., \& Ganesh, L. S. (2006). Modelling and assessment of critical risks in BOT road projects. Construction Management and Economics, 24(4), 407-424. https://doi.org/10.1080/01446190500435275

Wetzel, C., \& Vogdt, F. (2007). Technical improvement of housing envelopes in Germany. In L. Bragança, C. Wetzel, V. Buhagiar, \& L. G. W. Verhoef (Eds.), Improving the quality of existing urban building envelopes - façades and roofs (pp. 4648). Amsterdam: IOS Press BV.

Wilson, K. J. (2017). An investigation of dependence in expert judgement studies with multiple experts. International Journal of Forecasting, 33(1), 325-336.

https://doi.org/10.1016/j.ijforecast.2015.11.014

Woodward, D. G. (1997). Life cycle costing-theory, information acquisition and application. International Journal of Project Management, 15(6), 335-344.

https://doi.org/10.1016/S0263-7863(96)00089-0

\section{Appendix}

Table A1. Data for equation (1)

\begin{tabular}{|c|c|c|c|c|c|c|c|c|c|c|c|c|c|c|c|}
\hline 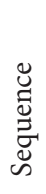 & 要 & 芯 & Factor & $\underset{\mathscr{c}}{\tilde{E}}$ & 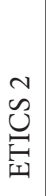 & 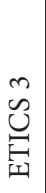 & $\vec{z}$ & 尚 & 邹 & 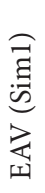 & 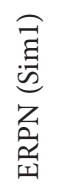 & 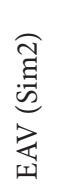 & 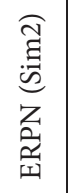 & 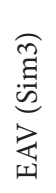 & 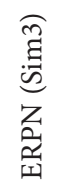 \\
\hline 1 & S1a & $\mathrm{S}$ & Substrate is covered with grease or oil & & $\mathrm{x}$ & $\mathrm{x}$ & 1.00 & 1.20 & 2.00 & & & 101 & 121 & 113 & 135 \\
\hline 2 & S1b & $\mathrm{S}$ & Substrate is covered with grease or oil & $\mathrm{x}$ & & & 1.00 & 1.40 & 1.63 & 98 & 137 & & & & \\
\hline 3 & S2a & $\mathrm{S}$ & Substrate is covered with dust or dirt & & $\mathrm{x}$ & $\mathrm{x}$ & 2.40 & 1.40 & 2.00 & & & 101 & 339 & 113 & 378 \\
\hline 4 & $\mathrm{~S} 2 \mathrm{~b}$ & $\mathrm{~S}$ & Substrate is covered with dust or dirt & $\mathrm{x}$ & & & 2.40 & 1.60 & 1.63 & 98 & 375 & & & & \\
\hline 5 & S3a & $S$ & Substrate is covered with biological growth & & $\mathrm{x}$ & $\mathrm{x}$ & 2.80 & 1.60 & 2.33 & & & 101 & 451 & 112 & 504 \\
\hline 6 & $\mathrm{~S} 3 \mathrm{~b}$ & $\mathrm{~S}$ & Substrate is covered with biological growth & $\mathrm{x}$ & & & 3.00 & 1.60 & 1.88 & 98 & 468 & & & & \\
\hline 7 & $\mathrm{~S} 4 \mathrm{a}$ & $\mathrm{S}$ & $\begin{array}{l}\text { Substrate is covered with paint or other } \\
\text { material which can chemically react with } \\
\text { adhesive }\end{array}$ & & $\mathrm{x}$ & $\mathrm{x}$ & 2.40 & 2.80 & 2.17 & & & 101 & 678 & 113 & 756 \\
\hline 8 & $\mathrm{~S} 4 \mathrm{~b}$ & $\mathrm{~S}$ & $\begin{array}{l}\text { Substrate is covered with paint or other } \\
\text { material which can chemically react with } \\
\text { adhesive }\end{array}$ & $\mathrm{x}$ & & & 2.60 & 3.00 & 1.75 & 98 & 762 & & & & \\
\hline 9 & S5a & $\mathrm{S}$ & $\begin{array}{l}\text { Substrate is under required load-bearing } \\
\text { capacity }\end{array}$ & & $\mathrm{x}$ & $\mathrm{x}$ & 2.20 & 3.20 & 1.00 & & & 101 & 714 & 113 & 797 \\
\hline 10 & S5b & $S$ & $\begin{array}{l}\text { Substrate is under required load-bearing } \\
\text { capacity }\end{array}$ & $\mathrm{x}$ & & & 1.60 & 3.40 & 0.83 & 98 & 534 & & & & \\
\hline 11 & S6a & $S$ & $\begin{array}{l}\text { Substrate has large unevenness or has } \\
\text { detached areas }\end{array}$ & & $\mathrm{x}$ & $\mathrm{x}$ & 3.60 & 1.80 & 2.17 & & & 101 & 653 & 113 & 729 \\
\hline
\end{tabular}


End of Table A1

\begin{tabular}{|c|c|c|c|c|c|c|c|c|c|c|c|c|c|c|c|}
\hline $\begin{array}{l}\tilde{U} \\
\tilde{\Xi} \\
\tilde{\Xi} \\
\tilde{D}\end{array}$ & $\Theta$ & 离 & Factor & $\underset{ت}{\vec{U}}$ & $\underset{v}{N}$ & $\underbrace{m}_{=1}$ & 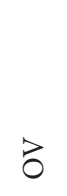 & $\vec{\partial}$ & 光 & 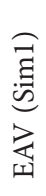 & 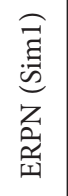 & 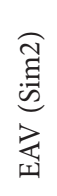 & 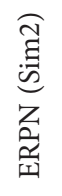 & 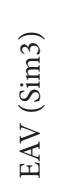 & 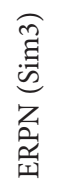 \\
\hline 12 & S6b & $S$ & $\begin{array}{l}\text { Substrate has large unevenness or has } \\
\text { detached areas }\end{array}$ & $\mathrm{x}$ & & & 3.00 & 1.60 & 1.33 & 98 & 470 & & & & \\
\hline 13 & S7a & $S$ & $\begin{array}{l}\text { Unsuitable surface (too smooth) which } \\
\text { reduces adhesion properties }\end{array}$ & & $\mathrm{x}$ & $\mathrm{x}$ & 2.00 & 3.33 & 2.67 & & & 101 & 670 & 112 & 748 \\
\hline 14 & S7b & $S$ & $\begin{array}{l}\text { Unsuitable surface (too smooth) which } \\
\text { reduces adhesion properties }\end{array}$ & $\mathrm{x}$ & & & 2.00 & 3.67 & 1.88 & 98 & 716 & & & & \\
\hline 15 & S8a & $S$ & $\begin{array}{l}\text { Substrate has very low humidity (inorganic } \\
\text { adhesive) }\end{array}$ & & $\mathrm{x}$ & $\mathrm{x}$ & 2.25 & 2.50 & 1.88 & & & 101 & 568 & 113 & 634 \\
\hline 16 & S8b & $S$ & $\begin{array}{l}\text { Substrate has very low humidity (inorganic } \\
\text { adhesive) }\end{array}$ & $\mathrm{x}$ & & & 2.50 & 2.50 & 1.63 & 98 & 611 & & & & \\
\hline 17 & S9a & $S$ & $\begin{array}{l}\text { Substrate is very wet (raining in prior to } \\
\text { application of adhesive) }\end{array}$ & & $\mathrm{x}$ & $\mathrm{x}$ & 2.20 & 1.80 & 2.00 & & & 101 & 400 & 113 & 446 \\
\hline 18 & S9b & $S$ & $\begin{array}{l}\text { Substrate is very wet (raining in prior to } \\
\text { application of adhesive) }\end{array}$ & $\mathrm{x}$ & & & 2.20 & 2.00 & 1.50 & 98 & 430 & & & & \\
\hline 19 & S10a & $S$ & $\begin{array}{l}\text { Substrate is frozen during the application } \\
\text { (inorganic adhesive) }\end{array}$ & & $\mathrm{x}$ & $\mathrm{x}$ & 1.40 & 2.20 & 1.17 & & & 101 & 312 & 113 & 348 \\
\hline 20 & S10b & $S$ & $\begin{array}{l}\text { Substrate is frozen during the application } \\
\text { (inorganic adhesive) }\end{array}$ & $\mathrm{x}$ & & & 1.40 & 2.20 & 0.75 & 98 & 302 & & & & \\
\hline 21 & M1a & $\mathrm{D}$ & Unsuitable mixture storage conditions & & $\mathrm{x}$ & $\mathrm{x}$ & 0.80 & 3.00 & 1.75 & & & 101 & 243 & 113 & 271 \\
\hline 22 & M1b & $\mathrm{D}$ & Unsuitable mixture storage conditions & $\mathrm{x}$ & & & 0.80 & 3.00 & 1.25 & 98 & 235 & & & & \\
\hline 23 & M2a & $\mathrm{D}$ & The mixing procedures do not remove clots & & $\mathrm{x}$ & $\mathrm{x}$ & 1.40 & 2.60 & 1.75 & & & 101 & 368 & 113 & 411 \\
\hline 24 & M2b & $\mathrm{D}$ & The mixing procedures do not remove clots & $\mathrm{x}$ & & & 1.20 & 2.60 & 1.25 & 98 & 305 & & & & \\
\hline 25 & M3a & $\mathrm{D}$ & High share of kneading water & & $\mathrm{x}$ & $\mathrm{x}$ & 1.40 & 3.00 & 3.50 & & & 100 & 421 & 112 & 469 \\
\hline 26 & M3b & $\mathrm{D}$ & High share of kneading water & $\mathrm{x}$ & & & 1.80 & 3.00 & 3.17 & 97 & 523 & & & & \\
\hline 27 & M4a & $\mathrm{D}$ & Low share of kneading water & & $\mathrm{x}$ & $\mathrm{x}$ & 1.50 & 3.00 & 2.67 & & & 101 & 453 & 112 & 505 \\
\hline 28 & M4b & $\mathrm{D}$ & Low share of kneading water & $\mathrm{x}$ & & & 1.50 & 3.00 & 1.83 & 98 & 439 & & & & \\
\hline 29 & D1a & $\mathrm{D}$ & $\begin{array}{l}\text { Missing adhesive on the edges of } \\
\text { insulation (polystyrene) }\end{array}$ & & $\mathrm{x}$ & & 1.50 & 3.25 & 3.13 & & & 62 & 302 & & \\
\hline 30 & D1b & $\mathrm{D}$ & $\begin{array}{l}\text { Missing adhesive on the edges of } \\
\text { insulation (polystyrene) }\end{array}$ & $\mathrm{x}$ & & & 1.50 & 3.25 & 2.75 & 97 & 474 & & & & \\
\hline 31 & $\mathrm{D} 2 \mathrm{a}$ & $\mathrm{D}$ & $\begin{array}{l}\text { Missing adhesive in the centre of } \\
\text { insulation (polystyrene) }\end{array}$ & & $\mathrm{x}$ & & 1.25 & 2.75 & 4.00 & & & 100 & 343 & & \\
\hline 32 & $\mathrm{D} 2 \mathrm{~b}$ & $\mathrm{D}$ & $\begin{array}{l}\text { Missing adhesive in the centre of } \\
\text { insulation (polystyrene) }\end{array}$ & $\mathrm{x}$ & & & 1.25 & 2.75 & 2.75 & 97 & 334 & & & & \\
\hline
\end{tabular}

Table A2. Data for equation (2)

\begin{tabular}{|c|c|c|c|c|c|c|c|c|c|c|c|c|c|c|c|}
\hline 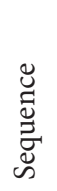 & $\ominus$ & 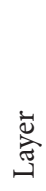 & Factor & 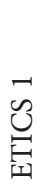 & 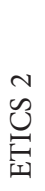 & 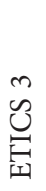 & b & $\vec{a}$ & 亗 & 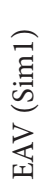 & 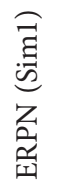 & 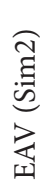 & 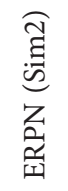 & 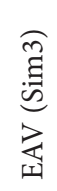 & 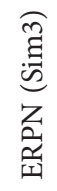 \\
\hline 33 & D3a & $\mathrm{D}$ & Insufficient adhesive surface area & & $\mathrm{x}$ & $\mathrm{x}$ & 2.75 & 2.50 & 6.00 & & & 99 & 680 & 110 & 758 \\
\hline 34 & $\mathrm{D} 3 \mathrm{~b}$ & $\mathrm{D}$ & Insufficient adhesive surface area & $\mathrm{x}$ & & & 2.75 & 2.50 & 5.63 & 96 & 658 & & & & \\
\hline 35 & D4 & $\mathrm{D}$ & $\begin{array}{l}\text { Adhesive is not rubbed into insulation } \\
\text { plate (mineral wool) }\end{array}$ & & & $\mathrm{x}$ & 2.00 & 3.00 & 5.50 & & & & & 111 & 664 \\
\hline 36 & D5 & $\mathrm{D}$ & $\begin{array}{l}\text { Adhesive is not treated with notch towel } \\
\text { (mineral wool) }\end{array}$ & & & $\mathrm{x}$ & 2.33 & 3.00 & 6.17 & & & & & 110 & 772 \\
\hline 37 & $\mathrm{D} 7 \mathrm{a}$ & $\mathrm{D}$ & Working time of the adhesive is exceeded & & $\mathrm{x}$ & $\mathrm{x}$ & 1.80 & 2.60 & 5.38 & & & 99 & 464 & 111 & 518 \\
\hline 38 & $\mathrm{D} 7 \mathrm{~b}$ & $\mathrm{D}$ & Working time of the adhesive is exceeded & $\mathrm{x}$ & & & 1.80 & 2.80 & 0.83 & 98 & 495 & & & & \\
\hline
\end{tabular}


End of Table A2

\begin{tabular}{|c|c|c|c|c|c|c|c|c|c|c|c|c|c|c|c|}
\hline 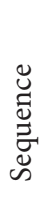 & $\theta$ & స్త్ర & Factor & $\underset{ت}{\vec{U}}$ & $\underset{=}{N}$ & $\underset{n}{\infty}$ & $\vec{z}$ & $\vec{a}$ & 䛼 & $\begin{array}{l}\widehat{\vec{\Xi}} \\
\text { 递 } \\
\text { 齐 }\end{array}$ & 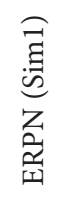 & 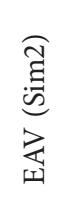 & 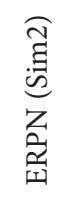 & 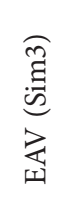 & 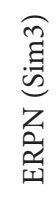 \\
\hline 39 & D8a & $\mathrm{D}$ & $\begin{array}{l}\text { Low pressure during application of } \\
\text { insulation plates }\end{array}$ & & $\mathrm{x}$ & $\mathrm{x}$ & 2.67 & 3.00 & 2.00 & & & 101 & 807 & 113 & 901 \\
\hline 40 & $\mathrm{D} 8 \mathrm{~b}$ & $\mathrm{D}$ & $\begin{array}{l}\text { Low pressure during application of } \\
\text { insulation plates }\end{array}$ & $\mathrm{x}$ & & & 2.00 & 3.00 & 1.50 & 98 & 587 & & & & \\
\hline 41 & D9a & $\mathrm{D}$ & Large unevenness of the adhesive layer & & $\mathrm{x}$ & $\mathrm{x}$ & 1.67 & 3.50 & 3.25 & 0 & & 100 & 585 & 112 & 653 \\
\hline 42 & $\mathrm{D} 9 \mathrm{~b}$ & $\mathrm{D}$ & Large unevenness of the adhesive layer & $\mathrm{x}$ & & & 1.67 & 3.50 & 2.00 & 98 & 569 & & & & \\
\hline 43 & M9a & $\mathrm{D}$ & $\begin{array}{l}\text { Low temperature (freezing) during } \\
\text { application and/or curing process }\end{array}$ & & $\mathrm{x}$ & $\mathrm{x}$ & 1.40 & 2.20 & 3.63 & & & 100 & 308 & 112 & 344 \\
\hline 44 & M9b & $\mathrm{D}$ & $\begin{array}{l}\text { Low temperature (freezing) during } \\
\text { application and/or curing process }\end{array}$ & $\mathrm{x}$ & & & 1.60 & 2.40 & 1.38 & 98 & 376 & & & & \\
\hline 45 & M10a & $\mathrm{D}$ & $\begin{array}{l}\text { High temperature (hot) during curing } \\
\text { process }\end{array}$ & & $\mathrm{x}$ & $\mathrm{x}$ & 1.80 & 2.60 & 1.50 & & & 101 & 474 & 113 & 528 \\
\hline 46 & M10b & $\mathrm{D}$ & $\begin{array}{l}\text { High temperature (hot) during curing } \\
\text { process }\end{array}$ & $\mathrm{x}$ & & & 1.80 & 2.60 & 1.25 & 98 & 458 & & & & \\
\hline 47 & M11a & $\mathrm{D}$ & Low humidity (dry) during curing process & & $\mathrm{x}$ & $\mathrm{x}$ & 2.33 & 3.00 & 2.00 & & & 101 & 706 & 113 & 788 \\
\hline 48 & M11b & $\mathrm{D}$ & Low humidity (dry) during curing process & $\mathrm{x}$ & & & 2.33 & 3.00 & 1.67 & 98 & 684 & & & & \\
\hline 49 & M8 & $\mathrm{D}$ & $\begin{array}{l}\text { Not recommended ingredients added to } \\
\text { the mixture }\end{array}$ & $\mathrm{x}$ & $\mathrm{x}$ & $\mathrm{x}$ & 1.80 & 2.60 & 1.63 & 98 & 457 & 101 & 473 & 113 & 528 \\
\hline 50 & I1 & I & $\begin{array}{l}\text { Polystyrene is exposed to UV-radiation for } \\
\text { a extended period }\end{array}$ & $\mathrm{x}$ & $\mathrm{x}$ & & 1.25 & 1.40 & 2.75 & 97 & 170 & 101 & 176 & & \\
\hline 51 & $\mathrm{I} 2$ & I & $\begin{array}{l}\text { Insulation plates are installed shortly after } \\
\text { manufacturing (unfinished diffusion process }\end{array}$ & $\mathrm{x}$ & $\mathrm{x}$ & & 1.75 & 3.50 & 2.13 & 97 & 597 & 101 & 618 & & \\
\hline 52 & I3a & I & $\begin{array}{l}\text { Mineral wool insulation plates have very } \\
\text { high relative humidity (are wet }\end{array}$ & & & $\mathrm{x}$ & 1.20 & 2.40 & 1.00 & & & & & 113 & 326 \\
\hline 53 & $\mathrm{I} 3 \mathrm{~b}$ & I & $\begin{array}{l}\text { Insulation plates which have very high } \\
\text { relative humidity (wet) }\end{array}$ & $\mathrm{x}$ & $\mathrm{x}$ & & 1.50 & 3.00 & 2.25 & 97 & 438 & 101 & 454 & & \\
\hline 54 & I4 & I & $\begin{array}{l}\text { Continuous gaps between substrate and } \\
\text { insulation material }\end{array}$ & $\mathrm{x}$ & $\mathrm{x}$ & $\mathrm{x}$ & 1.40 & 3.20 & 1.83 & 98 & 437 & 101 & 453 & 113 & 505 \\
\hline 55 & I5 & I & $\begin{array}{l}\text { Corners of neighbouring insulation plates } \\
\text { are crossed or too close }\end{array}$ & $\mathrm{x}$ & $\mathrm{x}$ & $\mathrm{x}$ & 2.25 & 1.25 & 6.75 & 95 & 268 & 98 & 277 & 110 & 309 \\
\hline 56 & I6 & I & Corners of the openings have crossed joints & $\mathrm{x}$ & $\mathrm{x}$ & $\mathrm{x}$ & 2.80 & 1.20 & 2.63 & 97 & 327 & 101 & 338 & 112 & 377 \\
\hline 57 & I7 & I & $\begin{array}{l}\text { Insulation plates joint width of } \\
\text { neighbouring insulation plates is too wide }\end{array}$ & $\mathrm{x}$ & $\mathrm{x}$ & $\mathrm{x}$ & 1.50 & 1.00 & 4.63 & 96 & 144 & 100 & 149 & 111 & 167 \\
\hline 58 & I8 & I & $\begin{array}{l}\text { Large height difference between } \\
\text { neighbouring insulation plates }\end{array}$ & $\mathrm{x}$ & $\mathrm{x}$ & $\mathrm{x}$ & 2.00 & 2.00 & 2.50 & 97 & 389 & 101 & 403 & 112 & 449 \\
\hline 59 & I9 & I & $\begin{array}{l}\text { Broken areas of the insulation plates are } \\
\text { not filled with same material }\end{array}$ & $\mathrm{x}$ & $\mathrm{x}$ & $\mathrm{x}$ & 2.25 & 1.25 & 6.13 & 95 & 268 & 99 & 278 & 110 & 310 \\
\hline 60 & $\mathrm{I} 10$ & $\mathrm{I}$ & Missing or narrow fire reluctant areas & $\mathrm{x}$ & $\mathrm{x}$ & & 1.50 & 1.25 & 0.50 & 98 & 184 & 102 & 191 & & \\
\hline 61 & A1 & A & Increased diameter of drilled anchor hole & & $\mathrm{x}$ & $\mathrm{x}$ & 1.50 & 3.00 & 5.50 & & & 61 & 275 & 61 & 275 \\
\hline 62 & A 10 & A & Hole of the anchor is not cleaned & & $\mathrm{x}$ & $\mathrm{x}$ & 1.33 & 2.33 & 1.17 & & & 63 & 195 & 63 & 195 \\
\hline 63 & A5 & A & Location of anchors is not as foreseen & & $\mathrm{x}$ & $\mathrm{x}$ & 1.67 & 1.33 & 1.67 & & & 62 & 139 & 62 & 139 \\
\hline 64 & A3 & A & $\begin{array}{l}\text { Decreased amount of anchors in the } \\
\text { continuous areas }\end{array}$ & & $\mathrm{x}$ & $\mathrm{x}$ & 2.50 & 1.25 & 4.17 & & & 62 & 193 & 62 & 193 \\
\hline 65 & A8 & A & $\begin{array}{l}\text { Decreased amount of anchors in the } \\
\text { corner areas }\end{array}$ & & $\mathrm{x}$ & $\mathrm{x}$ & 1.67 & 1.33 & 2.50 & & & 62 & 138 & 62 & 138 \\
\hline 66 & A9 & A & Usage of unsuitable anchor type & & $\mathrm{x}$ & $\mathrm{x}$ & 2.20 & 2.40 & 3.00 & & & 62 & 327 & 62 & 327 \\
\hline 67 & A2 & A & Decreased diameter of anchor plate & & $\mathrm{x}$ & $\mathrm{x}$ & 1.33 & 1.00 & 5.25 & & & 61 & 82 & 61 & 82 \\
\hline 68 & A6 & $\mathrm{A}$ & $\begin{array}{l}\text { Anchor plate is installed too deeply into } \\
\text { insulation material }\end{array}$ & & $\mathrm{x}$ & $\mathrm{x}$ & 2.40 & 1.00 & 3.75 & & & 62 & 148 & 62 & 148 \\
\hline
\end{tabular}


Table A3. Data for equation (3)

\begin{tabular}{|c|c|c|c|c|c|c|c|c|c|c|c|c|c|c|c|}
\hline $\begin{array}{l}\ddot{\mathscr{E}} \\
\stackrel{\Xi}{\Xi} \\
\ddot{\Xi}\end{array}$ & $\Theta$ & 离 & Factor & $\underset{\tilde{U}}{\tilde{U}}$ & 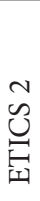 & 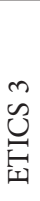 & 8 & 尚 & 号 & 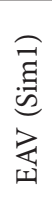 & 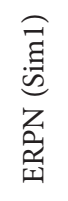 & 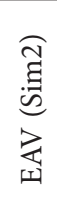 & 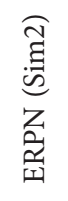 & 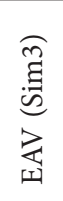 & 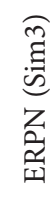 \\
\hline 69 & A7 & $\mathrm{A}$ & $\begin{array}{l}\text { Anchor plate is placed too high on the } \\
\text { surface of insulation material }\end{array}$ & & $\mathrm{x}$ & $\mathrm{x}$ & 1.75 & 1.00 & 0.83 & & & 63 & 110 & 63 & 110 \\
\hline 70 & R1 & $\mathrm{R}$ & $\begin{array}{l}\text { External layer of the insulation plate is too } \\
\text { smooth, reduced adhesion }\end{array}$ & $\mathrm{x}$ & $\mathrm{x}$ & & 2.00 & 3.00 & 2.13 & 62 & 374 & 62 & 374 & & \\
\hline 71 & M1c & $\mathrm{R}$ & Unsuitable material storage conditions & $\mathrm{x}$ & $\mathrm{x}$ & $\mathrm{x}$ & 1.00 & 3.00 & 0.67 & 63 & 188 & 63 & 188 & 63 & 188 \\
\hline 72 & M2c & $\mathrm{R}$ & The mixing procedures do not remove clots & $\mathrm{x}$ & $\mathrm{x}$ & $\mathrm{x}$ & 1.20 & 2.20 & 0.67 & 63 & 166 & 63 & 166 & 63 & 166 \\
\hline 73 & M3c & $\mathrm{R}$ & High share of kneading water & $\mathrm{x}$ & $\mathrm{x}$ & $\mathrm{x}$ & 1.80 & 2.20 & 0.75 & 63 & 248 & 63 & 248 & 63 & 248 \\
\hline 74 & M4c & $\mathrm{R}$ & Low share of kneading water & $\mathrm{x}$ & $\mathrm{x}$ & $\mathrm{x}$ & 1.40 & 2.60 & 1.25 & 63 & 228 & 63 & 228 & 63 & 228 \\
\hline 75 & R6 & $\mathrm{R}$ & Thin mortar layer & $\mathrm{x}$ & $\mathrm{x}$ & $\mathrm{x}$ & 2.75 & 2.00 & 4.63 & 61 & 338 & 61 & 338 & 61 & 338 \\
\hline 76 & $\mathrm{R} 2$ & $\mathrm{R}$ & Decreased overlap of the mesh & $\mathrm{x}$ & $\mathrm{x}$ & $\mathrm{x}$ & 1.75 & 3.00 & 2.13 & 62 & 327 & 62 & 327 & 62 & 327 \\
\hline 77 & R3 & $\mathrm{R}$ & Folded mesh & $\mathrm{x}$ & $\mathrm{x}$ & $\mathrm{x}$ & 1.00 & 2.50 & 1.75 & 62 & 156 & 62 & 156 & 62 & 156 \\
\hline 78 & $\mathrm{R} 4$ & $\mathrm{R}$ & Missing diagonal mesh & $\mathrm{x}$ & $\mathrm{x}$ & $\mathrm{x}$ & 2.00 & 2.50 & 1.38 & 63 & 313 & 63 & 313 & 63 & 313 \\
\hline 79 & R5 & $\mathrm{R}$ & $\begin{array}{l}\text { Mesh not filled with mortar, placed on the } \\
\text { edge of the layer }\end{array}$ & $\mathrm{x}$ & $\mathrm{x}$ & $\mathrm{x}$ & 2.00 & 2.33 & 2.00 & 62 & 291 & 62 & 291 & 62 & 291 \\
\hline 80 & R7 & $\mathrm{R}$ & Layer is not applied in wet to wet conditions & $\mathrm{x}$ & $\mathrm{x}$ & $\mathrm{x}$ & 2.50 & 3.00 & 2.38 & 62 & 466 & 62 & 466 & 62 & 466 \\
\hline 81 & $\mathrm{R} 8$ & $\mathrm{R}$ & Usage of not compatible mesh & $\mathrm{x}$ & $\mathrm{x}$ & $\mathrm{x}$ & 1.40 & 3.00 & 6.88 & 61 & 255 & 61 & 255 & 61 & 255 \\
\hline 82 & M9c & $\mathrm{R}$ & $\begin{array}{l}\text { Low temperature (freezing) during } \\
\text { application and/or curing process }\end{array}$ & $\mathrm{x}$ & $\mathrm{x}$ & $\mathrm{x}$ & 1.80 & 1.80 & 0.75 & 63 & 203 & 63 & 203 & 63 & 203 \\
\hline 83 & M10c & $\mathrm{R}$ & High temperature (hot) curing condition & $\mathrm{x}$ & $\mathrm{x}$ & $\mathrm{x}$ & 2.20 & 1.80 & 3.00 & 62 & 245 & 62 & 245 & 62 & 245 \\
\hline 84 & M11c & $\mathrm{R}$ & Low humidity (dry) curing conditions & $\mathrm{x}$ & $\mathrm{x}$ & $\mathrm{x}$ & 2.00 & 1.50 & 0.75 & 63 & 188 & 63 & 188 & 63 & 188 \\
\hline 85 & M12c & $\mathrm{R}$ & $\begin{array}{l}\text { Usage of winter mixtures during } \\
\text { unsuitable weather conditions }\end{array}$ & $\mathrm{x}$ & $\mathrm{x}$ & $\mathrm{x}$ & 1.00 & 3.00 & 4.50 & 61 & 184 & 61 & 184 & 61 & 184 \\
\hline 86 & $\mathrm{X} 6$ & $\mathrm{X}$ & $\begin{array}{l}\text { Shock resistance solution is not used (i.e. no } \\
\text { double reinforcement mesh, corner details with } \\
\text { metal or additional protective plate installed) }\end{array}$ & $\mathrm{x}$ & $\mathrm{x}$ & $\mathrm{x}$ & 2.60 & 2.00 & 0.50 & 98 & 511 & 102 & 529 & 114 & 590 \\
\hline 87 & F2 & $\mathrm{F}$ & $\begin{array}{l}\text { Reinforcement mixture or primary coat is } \\
\text { not cured }\end{array}$ & $\mathrm{x}$ & $\mathrm{x}$ & $\mathrm{x}$ & 2.00 & 3.00 & 0.75 & 28 & 169 & 28 & 169 & 28 & 169 \\
\hline 88 & $\mathrm{~F} 1$ & $\mathrm{~F}$ & Missing primer if required & $\mathrm{x}$ & $\mathrm{x}$ & $\mathrm{x}$ & 1.40 & 2.20 & 1.00 & 28 & 86 & 28 & 86 & 28 & 86 \\
\hline 89 & M1d & $\mathrm{F}$ & Unsuitable material storage conditions & $\mathrm{x}$ & $\mathrm{x}$ & $\mathrm{x}$ & 1.00 & 2.60 & 0.50 & 28 & 73 & 28 & 73 & 28 & 73 \\
\hline 90 & M2d & $\mathrm{F}$ & The mixing procedures do not remove clots & $\mathrm{x}$ & $\mathrm{x}$ & $\mathrm{x}$ & 1.00 & 2.00 & 0.33 & 28 & 56 & 28 & 56 & 28 & 56 \\
\hline 91 & M3d & $\mathrm{F}$ & High share of kneading water & $\mathrm{x}$ & $\mathrm{x}$ & $\mathrm{x}$ & 0.50 & 1.67 & 3.17 & 28 & 23 & 28 & 23 & 28 & 23 \\
\hline 92 & F3 & $\mathrm{F}$ & Thick render layer/ differences in thickness & $\mathrm{x}$ & $\mathrm{x}$ & $\mathrm{x}$ & 0.67 & 3.00 & 0.83 & 28 & 56 & 28 & 56 & 28 & 56 \\
\hline 93 & F4 & $\mathrm{F}$ & Thin render layer & $\mathrm{x}$ & $\mathrm{x}$ & $\mathrm{x}$ & 1.50 & 1.67 & 3.33 & 28 & 69 & 28 & 69 & 28 & 69 \\
\hline 94 & M9d & $\mathrm{F}$ & $\begin{array}{l}\text { Low temperature (freezing) during } \\
\text { application and/or curing process }\end{array}$ & $\mathrm{x}$ & $\mathrm{x}$ & $\mathrm{x}$ & 1.50 & 1.00 & 0.50 & 28 & 42 & 28 & 42 & 28 & 42 \\
\hline 95 & M10d & $\mathrm{F}$ & High temperature (hot) curing conditions & $\mathrm{x}$ & $\mathrm{x}$ & $\mathrm{x}$ & 2.20 & 1.40 & 0.83 & 28 & 87 & 28 & 87 & 28 & 87 \\
\hline 96 & M11d & $\mathrm{F}$ & Low humidity (dry) curing conditions & $\mathrm{x}$ & $\mathrm{x}$ & $\mathrm{x}$ & 2.50 & 1.50 & 0.83 & 28 & 105 & 28 & 105 & 28 & 105 \\
\hline 97 & $\mathrm{X} 1$ & $\mathrm{X}$ & $\begin{array}{l}\text { Structural expansion joint is not installed/ } \\
\text { finished properly }\end{array}$ & $\mathrm{x}$ & $\mathrm{x}$ & $\mathrm{x}$ & 1.40 & 1.80 & 2.38 & 97 & 245 & 101 & 254 & 112 & 283 \\
\hline 98 & $\mathrm{X} 2$ & $\mathrm{X}$ & $\begin{array}{l}\text { Windowsill is not appropriately finished } \\
\text { (i.e. curved upwards, proper sealants) }\end{array}$ & $\mathrm{x}$ & $\mathrm{x}$ & $\mathrm{x}$ & 3.60 & 1.60 & 2.38 & 97 & 561 & 101 & 580 & 112 & 648 \\
\hline 99 & X3 & $\mathrm{X}$ & $\begin{array}{l}\text { Unsolved rainwater drainage (i.e. } \\
\text { drainpipe or drip profiles not used) }\end{array}$ & $\mathrm{x}$ & $\mathrm{x}$ & $\mathrm{x}$ & 3.00 & 1.20 & 2.17 & 97 & 351 & 101 & 363 & 113 & 405 \\
\hline 100 & $\mathrm{X} 4$ & $X$ & $\begin{array}{l}\text { Fixed frame connection is not finished } \\
\text { accurately (i.e. missing sealants) }\end{array}$ & $\mathrm{x}$ & $\mathrm{x}$ & $\mathrm{x}$ & 3.20 & 1.80 & 1.88 & 98 & 562 & 101 & 582 & 113 & 649 \\
\hline 101 & $\mathrm{X} 5$ & $\mathrm{X}$ & $\begin{array}{l}\text { Roof edge covers are not installed correctly } \\
\text { (i.e. vertical detail too short) }\end{array}$ & $\mathrm{x}$ & $\mathrm{x}$ & $\mathrm{x}$ & 2.60 & 2.00 & 1.88 & 98 & 507 & 101 & 525 & 113 & 586 \\
\hline 102 & $\mathrm{X} 7$ & $\mathrm{X}$ & $\begin{array}{l}\text { Unfinished penetrations through the } \\
\text { system (i.e. fixed without sealants) }\end{array}$ & $\mathrm{x}$ & $\mathrm{x}$ & $\mathrm{x}$ & 3.40 & 1.20 & 2.50 & 97 & 397 & 101 & 411 & 112 & 458 \\
\hline 103 & $\mathrm{X} 8$ & $\mathrm{X}$ & $\begin{array}{l}\text { Unsuitable plinth detail solutions (i.e. } \\
\text { incorrect fixing, overlapping of details) }\end{array}$ & $\mathrm{x}$ & $\mathrm{x}$ & $\mathrm{x}$ & 2.60 & 1.40 & 1.50 & 98 & 356 & 101 & 368 & 113 & 411 \\
\hline
\end{tabular}

